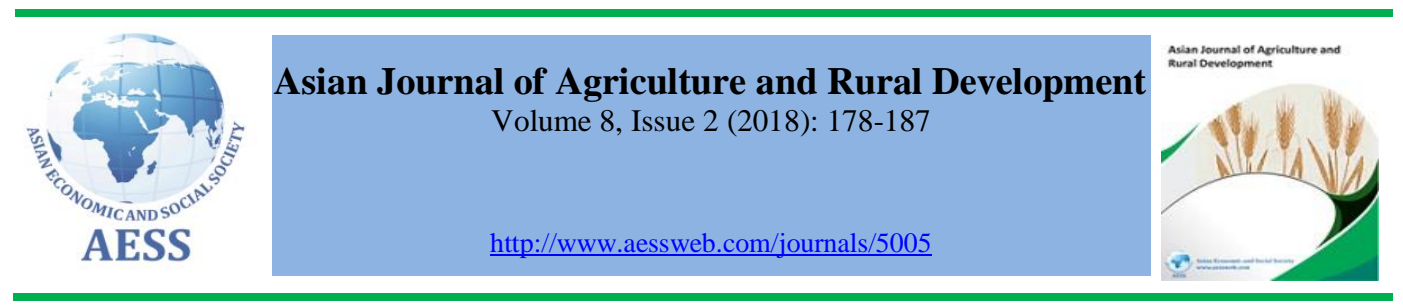

\title{
GROWTH INDUCTION OF CAVENDISH BUDS (Musa Acuminata L.) ON DIFFERENCE CONCENTRATION OF IBA AND BA IN VITRO
}

Subandi, M.

Arkhan Jannata,

Sofiya Hasani

ARTICLE HISTORY:

Received: 04-Aug-2018

Accepted: 02-Jan-2019

Online Available: $24-J a n-$ 2019

Keywords:

Bud,

Longger,

Propagation,

Seeds
Department Agrotechnology, Faculty of Science and Technology, The State Islamic University of Sunan Gunung Djati of Bandung, Indonesia

$\bowtie$ mhd.subandi@uinsgd.ac.id (Corresponding author)

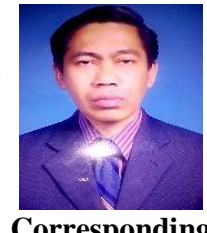

author

\begin{tabular}{|c|}
\hline \\
\hline 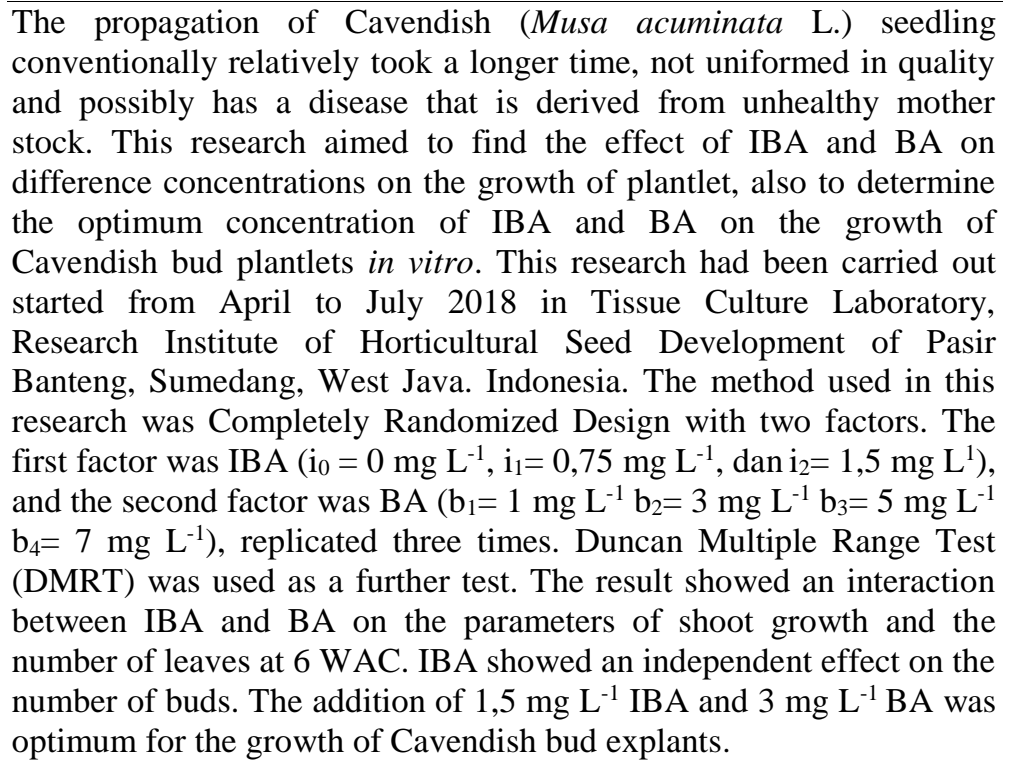 \\
\hline
\end{tabular}

\section{Contribution/ Originality}

The current research analysed the effect of IBA and BA on difference concentrations on the growth of plantlet, and determine the optimum concentration of IBA and BA on the growth of Cavendish bud plantlets in vitro on the basis of recent data.

DOI: 10.18488/journal.1005/2018.8.2/1005.2.178.187

ISSN (P): 2304-1455/ISSN (E):2224-4433

How to cite: Subandi, M., Arkhan Jannata and Sofiya Hasani (2018). Growth induction of cavendish buds (Musa Acuminata L.) on difference concentration of IBA and BA in vitro. Asian Journal of Agriculture and Rural Development, 8(2), 178-187.

(C) 2018 Asian Economic and Social Society. All rights reserved. 


\section{INTRODUCTION}

Banana is a fruit that is often consumed compared to other fruits and is consumed without regard to the social level (Rahmawati and Erita, 2013). Apart from being easy to obtain and affordable, bananas have long been known as a delicious and nutritious fruit (Supriyanto et al., 1990). Bananas are also one of the main crops that are commonly planted by the community in addition to cassava, papaya, and jackfruit (Putranto and Taofik, 2014; Akpan and Udoh, 2017; Okebiorun and Jatto, 2017).

The type of banana that is currently in high demand and desired by the international market is Cavendish, but based on information from the Ministry of Agriculture (Directorate General of Horticulture, 2015) the development of Cavendish cultivars in Indonesia still faces obstacles for the attack of Fusarium wilt. Non-uniform quality and the rare use of quality seeds have become obstacles to Indonesia's banana export activities to other countries.

Another problem is to fulfill one hectare of land needed as many as 1000-2500 banana seedlings, while conventional propagation of banana seedlings has problems because of the relatively small number of tillers obtained, which is only about 5-10 tillers per clump per year (Yusnita and Hapsoro, 2013). According to (Bhosale et al., 2011; Subandi et al., 2018), for commercial purposes planting material can be obtained through tissue culture techniques. This technique produces high multiplication, is uniformly genetic, and the planting material is free of pests and diseases.

Growth and development of explants in tissue culture is further maximized by using Growth Regulating Substances (GRS). According to Lestari (2011), the use of GRS in tissue culture depends on the which of growth of the desired plant tissue. The formation of shoots explains in vitro culture is usually aided by applying GRS auxin and cytokinin (Zulkarnain, 2009). Auxin is actually a stimulating GRS for root formation, but Lu and Thorpe (1987) and Davies (1995) states that in the same medium, a combination of auxin and cytokinin will form synergism to spur shoot proliferation. IBA (Indole-3butyric Acid) is one of the auxiliary substances that is often used in tissue culture, because it has a more stable, easily available, relatively inexpensive and effective nature (Wattimena, 1988). Cytokinin is a hormone that plays a role in shoot growth (Triningsih et al., 2013). Benzyladenine (BA) is a type of cytokinin with propagul propagation effectiveness that is quite high, easy to obtain, relatively inexpensive, and stable so that it is widely used (Srivastava, 2002; Subandi et al., 2018a).

Srivastava (2002), reported IBA $0.0 \mathrm{mg} \mathrm{L}^{-1}$ and BA $1.5 \mathrm{mg} \mathrm{L}^{-1}$ had the best influence in the formation of the number of barangan banana shoots as much as 4.00 shoots per explant, Supriati (2010), reported on Amorang kepok banana that BA $1 \mathrm{mg} \mathrm{L}^{-1}$ in the media 1/4 MS was best for multiplication of shoots, Avivi and Ikrarwati (2004), in Abaca banana, $5 \mathrm{mg} \mathrm{L}^{-1} \mathrm{BA}$ had the same effect with kinetin $7 \mathrm{mg} \mathrm{L}^{-1}$ in producing plantlets.

This study aims to determine the effect of various concentrations of IBA and BA on the growth of shoots of Cavendish banana explants and determine the optimum level of IBA and BA concentration for the growth of Cavendish banana plantlets shoots in vitro.

\section{MATERIALS AND METHODS}

The research was conducted from April 2018 to July 2018 at the Research Institute of Horticultural Seed Development of Pasir Banteng, Sumedang, West Java. Indonesia. 
The tools used during the research took place, namely 1) sterilization equipment (bottle brush, autoclave, oven, toolbox); 2) media preparation equipment (culture bottles, stirring rods, timers, spatulas, magnetic stirrers, volumetric flasks, hot plates, analytical scales, measuring cups, $\mathrm{pH}$ meters, pipettes and pump pipettes); 3) dissection equipment (tweezers, scissors, handles and scalpel blades); 4) planting and incubation equipment (Laminar Air Flow Cabinet, petri dish, Bunsen, culture rack, air conditioner, thermo hydro meter, rubber band, hand sprayer); and 5) observation equipment (rulers, cameras and stationery).

The materials used during the research took place, namely banana plantlets Cavendish (Musa acuminata L.) SK3 (3rd subculture), Murashige and Skoog (MS) stock solution, IBA and BA Growth Regulating Substances, 70\% and 96\% alcohol, agar-agar, sugar, activated charcoal, tissue, detergent, methylated, aquadest, label stickers, plastic wrap and aluminum foil.

The experimental design carried out was a Factorial Completely Randomized Design method consisting of two factors, and three replications.

1) The first factor, the concentration of IBA (I) which consists of 3 levels of treatment, namely:

i0 = IBA $0.00 \mathrm{mg} \mathrm{L}^{-1}$

i1 $=$ IBA $0.75 \mathrm{mg} \mathrm{L}^{-1}$

i2 = IBA $1.50 \mathrm{mg} \mathrm{L}^{-1}$

2) The second factor, the concentration of BA (B) which consists of 4 levels of treatment, namely:

b1 = BA $1.00 \mathrm{mg} \mathrm{L}^{-1}$

$\mathrm{b} 2=\mathrm{BA} 3.00 \mathrm{mg} \mathrm{L}^{-1}$

$\mathrm{b} 3=\mathrm{BA} 5.00 \mathrm{mg} \mathrm{L}^{-1}$

b4 = BA $7.00 \mathrm{mg} \mathrm{L}^{-1}$

The treatment combination was 12 treatment units with each were replicated 3 implications which each bottle is filled with 1 explant. Of the 36 bottles of treatment, then each one was made a backup per bottle, so that the total number of trials was 72 bottles.

\subsection{Several parameters were observed including}

a. Early Growing Time: Observations were made from the beginning of planting until the first time shoots appeared. Criteria for new shoots that grow are the presence of protrusions from the surface of the explants pointing up

b. Number of shoots (fruit) The number of shoots was observed by counting the number of shoots formed in each live explant. The number of shoots is calculated every two weeks every 2, 4, 6 and 8 WAC.

c. Shoot height $(\mathrm{cm})$. The shoot height was observed by measuring the ruler from outside the culture bottle, starting from the base of the stem to the highest growing point. Measurements are made every two weeks every 2, 4, 6 and 8 WAC.

\subsection{Stage of research}

1. Sterilization of Space and Equipment Space sterilization (laboratory) is carried out by cleaning every corner of the room in the planting room, and incubation room. Especially for planting rooms, floors and tables in the room cleaned and sprayed using $96 \%$ alcohol every time before and after use. Dissection equipment is sterilized by washing with water and detergent. wet sterilized equipment in an autoclave at $121^{\circ} \mathrm{C}$ with a pressure of 15 psi for 60 minutes. Then dry sterilization by inserting the equipment into the oven at $100^{\circ} \mathrm{C}$ for 60 minutes. LAFC sterilization is done by activating UV light for 30-60 minutes before use and activating the blower, then. At the time of use, all parts of LAFC (except filter alpha) are sprayed with $70 \%$ alcohol and wiped with tissue. 
2. Preparing and Sterilizing Media The media composition was made according to the experimental level used to be mixed into MS media material. Media that has been mixed is cooked until boiling, then poured into a culture bottle, then covered with plastic and tightly tied using rubber. The media is coded according to the treatment using a sticker, then sterilized using an autoclave with a temperature of $121^{\circ} \mathrm{C}$ at a pressure of 15 psi for 30 minutes. After sterilization is complete, the media bottles are stored for 5 days in the incubation room before use.

\subsection{Planting explants}

3. Explanation planting is done inside LAFC. Before planting, LAFC and the equipment to be used are sterilized according to the method described in the equipment sterilization section. The explants were removed from the bottle and then cut off the shoots, then planted in the treatment medium as much as 1 explant / bottle using sterile tweezers. Before transferring explants, it is necessary to pay attention to the media that will be used in a sterile condition (there are no contaminants), and to anticipate contamination, the mouth of the bottle is burned with Bunsen before and after the explants are removed. The culture bottle that has been filled by the explant is then covered with plastic and tied with a rubber band, then tightened with plastic wrap.

\subsection{Cultivation/maintenance}

4. The culture bottles that have contained explants are stored neatly on top of the culture rack in the incubation chamber. Maintenance is carried out every day by noticing and maintaining cleanliness by ensuring that every equipment that enters the incubation chamber is sterile. The environmental conditions of the room are maintained so that the room temperature is stable between $27^{\circ} \mathrm{C}-29^{\circ} \mathrm{C}$ and $70 \%$ room humidity and $90 \%$ bottle moisture.

Spraying $70 \%$ alcohol on each culture bottle is done every day to prevent contamination. Explants undergoing contamination are recorded and separated so that contamination is not widespread.

\section{RESULTS AND DISCUSSION}

\subsection{The time of early shoots appears}

Shoots are new young branches that grow or prospective new plants that grow from parts of the plant (Rahardja and Wiryanta, 2003). The earlier the growth of shoots shows that the explant response to treatment is very good. The initial time for buds to appear varies in each treatment.

Table 1: Interactions of IBA and BA on the initial time of growing shoots (DAC)

\begin{tabular}{lcccc}
\hline IBA (i) & & & BA (b) & \\
& $\mathbf{b}_{\mathbf{1}}$ & $\mathbf{b}_{\mathbf{2}}$ & $\mathbf{b}_{\mathbf{3}}$ & $\mathbf{b}_{\mathbf{4}}$ \\
\hline $\mathrm{i} 0$ & $6,33 \mathrm{ab}$ & $8,33 \mathrm{a}$ & $5,33 \mathrm{a}$ & $15,67 \mathrm{a}$ \\
& $\mathrm{B}$ & $\mathrm{B}$ & $\mathrm{B}$ & $\mathrm{A}$ \\
$\mathrm{i} 1$ & $11,00 \mathrm{a}$ & $2,67 \mathrm{a}$ & $4,00 \mathrm{a}$ & $2,67 \mathrm{~b}$ \\
& $\mathrm{~A}$ & $\mathrm{~B}$ & $\mathrm{~B}$ & $\mathrm{~B}$ \\
$\mathrm{i} 2$ & $2,00 \mathrm{~b}$ & $2,33 \mathrm{a}$ & $2,33 \mathrm{a}$ & $3,33 \mathrm{~b}$ \\
& $\mathrm{~A}$ & $\mathrm{~A}$ & $\mathrm{~A}$ & $\mathrm{~A}$ \\
\hline
\end{tabular}

Note: The number followed by the same letter is not significantly different according to the Duncan Test at the 5\% level. Lowercase letters are read vertically (columns). The capital letter is read horizontal direction (line)

Based on Table 1, each IBA and BA concentration can affect the speed of explants on growing shoots. The initial time to grow the fastest shoots was found in i2 treatment when combined with the addition of BA at levels b1, b2, and b3. This means that lower BA concentrations will have the maximum effect in growing shoots when combined with IBA at a concentration of $1.5 \mathrm{mg} \mathrm{L}^{-1}$. On 
the contrary, the higher the concentration of BA used it actually resulted in the initial growth time of shoots occurred more slowly, which grew at $3.33 \mathrm{DAC}$ at the level of b4. This is allegedly closely related to Fahmi's (2013) disclosure, that the use of high concentrations of cytokinin can inhibit growth, poison and even kill explants, causing increased concentration in the BA treatment combined with i2 treatment, causing explants to grow slowly in growing shoots. The right cytokinin treatment to balance the initial growth time of shoots if without the addition of IBA (i0) is the treatment of $5 \mathrm{mg} \mathrm{L}^{-1} \mathrm{BA}$ (b3), whereas in IBA $0.75 \mathrm{mg} \mathrm{L}^{-1}$ (i1) you should add BA $3 \mathrm{mg} \mathrm{L}^{-1}$ (b2) or BA $7 \mathrm{mg} \mathrm{L}^{-1}$ (b4).

The treatment of $i 2 b 1$ is the treatment that has the best influence with the average shoots of Cavendish explants in this combination can grow starting from 2.00 DAC. In another sense, the concentration of $1.5 \mathrm{mg} \mathrm{L}^{-1}$ IBA when combined with BA $1 \mathrm{mg} \mathrm{L}^{-1}$ is able to grow shoots faster than other combinations. Based on this, the high or low concentrations of exogenous growth regulators are not necessarily absolute, with exogenous auxin concentrations increasing, it will cause barriers to the time of shoot growth to increase, since Enjoni (2004) states that the effect of explant growth in vitro depends on the growth regulators applied to the media, the concentration or concentration of the growth regulator given is closely related to the hormone content contained in explant.

1.
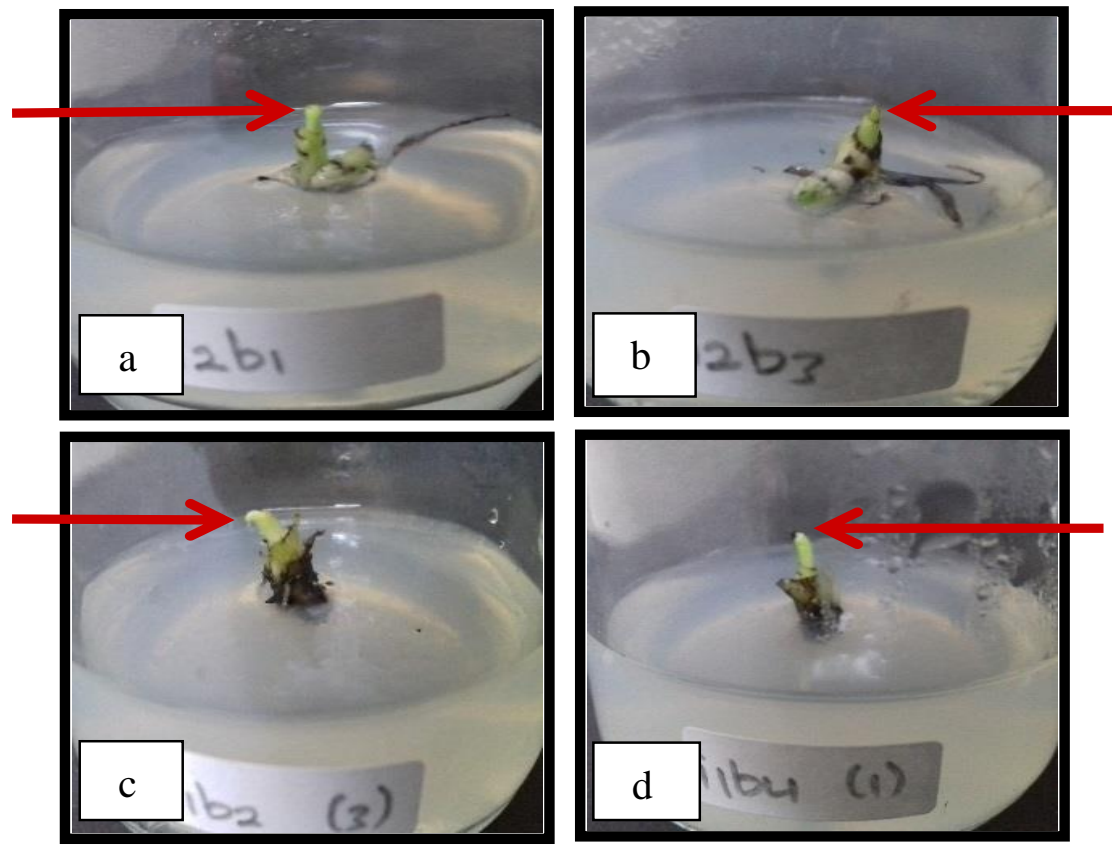

Figure 1: The initial time to grow shoots of Cavendish explants in treatments
a) i2b1 at $2.00 \mathrm{DAC}$;
b) i2b3 2.33 DAC;
c) i1b2 at 2.67 DAC;
d) i1b4 at 2.67 DAC.

The accuracy of the IBA and BA concentrations in the i2b1 treatment is affected by the interactions of auxin and cytokinin in the form of endogenous phytohormones from within the explants, thus spurring the growth of explant shoots earlier than the other treatments. The initial time to grow buds is an important parameter to be observed because the faster the shoot grows, the 
faster the growth of the shoot is expected, so that it can accelerate the multiplication stage to shorten the time in multiplication in vitro.

\subsection{Number of buds}

Growth in the number of buds is one of the important factors in tissue culture, because the number of buds indicates the success of the multiplication stage. Buds have an important role to become the main organ that will support the plant to keep growing and developing. Calculation of the number of buds carried out on the whole shoots that grow, both in the form of shoots originating from buds or adventitious shoots.

Observation of the number of buds did not correlate with the initial time of shoot growth in this study. The results of the variance analysis showed no significant interaction between IBA and BA in influencing the growth of the number of bud of Cavendish banana explants. The growth of the number of shoots in this study was influenced by independent factors from the existence of IBA from $2 \mathrm{WAC}$ to $8 \mathrm{WAC}$ with a very significant degree of influence.

Table 2: Independent effect of IBA on number of buds at 2 WAC, 4 WAC, 6 WAC, and 8 WAC

\begin{tabular}{|c|c|c|c|c|c|c|c|}
\hline \multirow{2}{*}{ Treatment } & \multicolumn{7}{|c|}{ Number of buds } \\
\hline & \multicolumn{2}{|c|}{$2 \mathrm{WAC}$} & \multicolumn{2}{|c|}{$4 \mathrm{WAC}$} & \multicolumn{2}{|c|}{$6 \mathrm{WAC}$} & 8 WAC \\
\hline & & & & & & & \\
\hline $\mathrm{i}_{0}$ & 1,00 & $\mathrm{a}$ & 1,50 & $\mathrm{a}$ & 1,67 & $\mathrm{a}$ & $1,83 \mathrm{a}$ \\
\hline$i_{1}$ & 1,42 & $\mathrm{a}$ & 2,17 & $\mathrm{a}$ & 2,67 & a & $3,33 \mathrm{a}$ \\
\hline $\begin{array}{l}\underline{i}_{2} \\
\text { BA }\end{array}$ & $\underline{3,33}$ & $\underline{\mathrm{b}}$ & $\underline{5,58}$ & $\underline{\mathrm{b}}$ & $\underline{8,17}$ & $\underline{b}$ & $\underline{9,08 \mathrm{~b}}$ \\
\hline$b_{1}$ & 1,89 & $\mathrm{a}$ & 2,89 & $\mathrm{a}$ & 3,78 & $\mathrm{a}$ & $3,89 \mathrm{a}$ \\
\hline $\mathrm{b}_{2}$ & 2,44 & $\mathrm{a}$ & 3,11 & a & 4,67 & $\mathrm{a}$ & $5,44 \mathrm{a}$ \\
\hline $\mathrm{b}_{3}$ & 1,56 & $\mathrm{a}$ & 2,78 & $\mathrm{a}$ & 3,56 & $\mathrm{a}$ & $3,89 \mathrm{a}$ \\
\hline $\mathrm{b}_{4}$ & 1,78 & $\mathrm{a}$ & 3,56 & $\mathrm{a}$ & 4,67 & $\mathrm{a}$ & $5,78 \mathrm{a}$ \\
\hline
\end{tabular}

Note: The mean value of each column marked with the same letter shows no significant difference based on Duncan's advanced test at the $5 \%$ level

The results of the analysis were carried out using Duncan's advanced test at a significant level of $5 \%$, indicating that the i2 (IBA) giving factor of $1.5 \mathrm{mg} \mathrm{L}^{-1}$ had the best effect in growing the number of bud in Cavendish banana as much as 3.33 buds at 2 WAC, 5.58 buds in 4 WAC, 8.17 buds at $6 \mathrm{WAC}$, and 9.08 buds at $8 \mathrm{WAC}$ (Table 2). The independent influence factor of BA itself did not show any significant effect on each level of treatment, but the highest effect was found at the level of treatment b2 with an average of 2.44 buds per explant at $2 \mathrm{WAC}$, the level of treatment b4 on average 3.55 buds per explant at $4 \mathrm{WAC}$, then $\mathrm{b} 2$ and $\mathrm{b} 4$ with an average of 4.66 buds per explant at $6 \mathrm{WAC}$, and at $8 \mathrm{WAC}$ the treatment level b4 was able to produce an average of 5.78 buds per explant.

Growth regulator IBA is an exogenous auxin hormone which functions to stimulate root growth in tissue culture. However, the results of observations showed that the treatment with auxin was lower, the growth in the number of shoots was not very visible. The growth of the number of buds is very increased in treatment i 2 (IBA $1.5 \mathrm{mg}^{\mathrm{L}-1}$ ). This can be caused by the good interaction between IBA and endogenous auxin hormones in Cavendish bananas, as revealed by George and Sherrington (1984) in their research which showed that explant growth and development can be influenced by interactions and balance between GRS exogenous GRS endogen (hormon). 

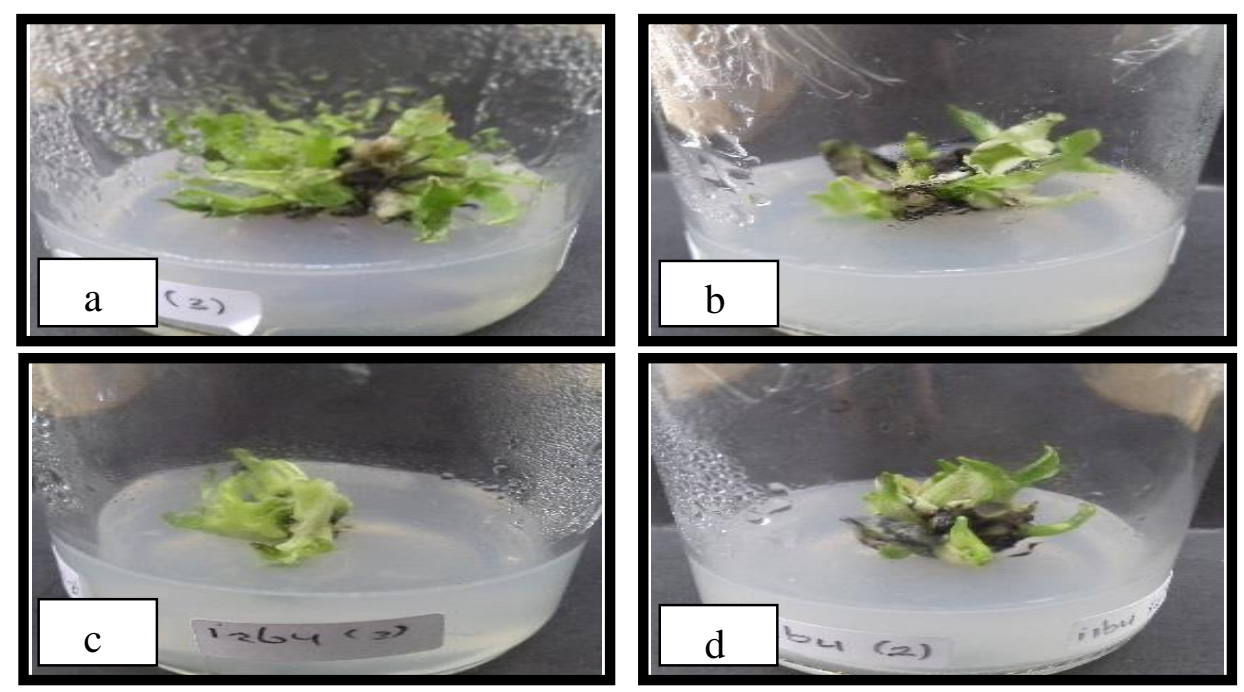

Figure 2: a) i2b2 treatment; b) i2b3 treatment; c) i2b4 treatment; d) i1b4 treatment

The combination of cytokinins with auxin which is appropriate can spur morphogenesis in bud formation (Flick et al., 1933), meaning that with a suitable combination, auxin as a root GRS can work with cytokinins to form buds in Cavendish culture.

Based on observations on 8 WAC (Figure 2), Cavendish banana explants with i2b2 treatment (IBA

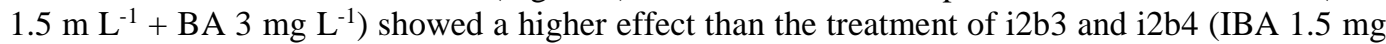
$\mathrm{L}^{-1}+\mathrm{BA} 5 \mathrm{mg} \mathrm{L}^{-1}$ ) and i2b4 (BA $1.5 \mathrm{mg} \mathrm{L}^{-1}+\mathrm{BA} 7 \mathrm{mg} \mathrm{L}^{-1}$ ), with an average number of buds that grew 11.67 shoots, while treatment ilb4 had an average the number of shoots is 7.67 buds.

\subsection{The height of buds}

The results of the variance analysis showed that there was no significant interaction between IBA and BA in growing Cavendish banana shoots during the observations that lasted from 2 WAC to 8 WAC. Very significant influence was shown independently by IBA at each observation conducted from 2 WAC to 8 WAC.

Table 3: Effect of independent IBA and BA on buds height at the age of 2 WAC, 4 WAC, 6 WAC, and 8 WAC

\begin{tabular}{|c|c|c|c|c|c|c|c|}
\hline \multirow{2}{*}{ Treatment } & \multicolumn{7}{|c|}{ Height of buds (cm) } \\
\hline & \multicolumn{2}{|c|}{$2 \mathrm{WAC}$} & \multicolumn{2}{|c|}{$4 \mathrm{WAC}$} & \multicolumn{2}{|c|}{6 WAC } & \multirow[t]{2}{*}{$8 \mathrm{WAC}$} \\
\hline & & & & & & & \\
\hline$i_{0}$ & 0,21 & $\mathrm{a}$ & 0,39 & $\mathrm{a}$ & 0,46 & $\mathrm{a}$ & $0,55 \mathrm{a}$ \\
\hline$i_{1}$ & 0,36 & $\mathrm{a}$ & 0,63 & $\mathrm{a}$ & 0,70 & $\mathrm{a}$ & $0,82 \mathrm{a}$ \\
\hline $\mathrm{i}_{2}$ & 0,54 & $a b$ & 1,01 & $\mathrm{~b}$ & 1,36 & $\mathrm{~b}$ & $1,51 \mathrm{~b}$ \\
\hline $\mathrm{BA}$ & & & & & & & \\
\hline$b_{1}$ & 0,34 & $\mathrm{a}$ & 0,64 & $\mathrm{a}$ & 0,81 & $\mathrm{a}$ & $0,97 \mathrm{a}$ \\
\hline$b_{2}$ & 0,40 & $\mathrm{a}$ & 0,72 & $\mathrm{a}$ & 0,89 & $\mathrm{a}$ & $1,06 \mathrm{a}$ \\
\hline$b_{3}$ & 0,35 & $\mathrm{a}$ & 0,58 & $\mathrm{a}$ & 0,79 & $\mathrm{a}$ & $0,84 \mathrm{a}$ \\
\hline $\mathrm{b}_{4}$ & 0,39 & $\mathrm{a}$ & 0,78 & $\mathrm{a}$ & 0,89 & $\mathrm{a}$ & $0,96 \mathrm{a}$ \\
\hline
\end{tabular}

Note: The mean value of each column marked with the same letter shows no significant difference based on Duncan's advanced test at the $5 \%$ level 
Through the results of further testing using Duncan at the significant level of 5\%, which is shown in Table 10, it is known that the treatment factor i2 (IBA $1.5 \mathrm{mg} \mathrm{L}^{-1}$ ) has a highly significant effect compared to other levels of IBA by growing Cavendish banana buds as high as $0.54 \mathrm{~cm}, 1.01 \mathrm{~cm}$, $1.36 \mathrm{~cm}$, and $1.51 \mathrm{~cm}$ in $2 \mathrm{WAC}, 4 \mathrm{WAC}, 6 \mathrm{WAC}$, and $8 \mathrm{WAC}$ in sequence. The application of $\mathrm{BA}$ at the level of treatment b2 (BA $3 \mathrm{mg} \mathrm{L}-1)$ is able to grow the best shoot height compared to other levels of BA treatment, which is as high as $1.06 \mathrm{~cm}$ at $8 \mathrm{WAC}$, but the effect is not significantly observed according to the results of statistical calculations due to comparisons which is not so significant with other levels of BA treatment.

On the observation data of treatment i $2 \mathrm{~b} 4$ (IBA $1.5 \mathrm{mg} \mathrm{L}^{-1}+\mathrm{BA} 7 \mathrm{mg} \mathrm{L}^{-1}$ ) at $2 \mathrm{WAC}-4$

WAC was the treatment with the highest growth of the best shoots with an average of $0.62-1.15 \mathrm{~cm}$ per explant. Then at $6 \mathrm{WAC}$ the highest buds were found in the treatment of $\mathrm{i} 2 \mathrm{~b} 2$ (IBA $1.5 \mathrm{mg} \mathrm{L}^{-1}$ + BA $3 \mathrm{mg} \mathrm{L}^{-1}$ ) with an average shoot height of $1.43 \mathrm{~cm}$ per explant. Then the treatment of $\mathrm{i} 2 \mathrm{~b} 1$ (IBA $1.5 \mathrm{mg} \mathrm{L}^{-1}+\mathrm{BA} 1 \mathrm{mg} \mathrm{L}^{-1}$ ) produced the best shoot height at $8 \mathrm{WAC}$ with an average height of $1.65 \mathrm{~cm}$ per explant. Changes in treatment in the best category are thought to be caused by plants needing time to absorb nutrients and respond differently.

Growth is usually seen in morphological changes in the form of tissue lengthening and enlargement (Karjadi and Buchory, 2007). Gardner et al. (1991) explains that in a narrow sense, growth means cell division, which results in an increase in the number and enlargement of cells, so that the increase in cell size causes increased shoot height marked by increased shoot size in explants. Increased shoot height in tissue culture as a sign of increased growth and ability of explants in adding new organs around the bud organs that have specific and important functions for future plant life.

The type and concentration of plant growth regulators that are appropriate for each plant are not the same because it depends on the genotype and physiological conditions of the plant tissue (Lestari, 2011). In addition, according to Fahmi (2013), too much growth regulating substances can actually inhibit, poison, and kill plants. Coupled with the scale of production, the use of regulating growth substances is too large to reduce the value of efficiency in the use of production costs.

\section{CONCLUSION}

1. The application of IBA and BA interacts with the initial time parameters of growing shoots.

2. Independently the application of IBA affects the parameters of the number of buds and buds height.

3. The optimum growth of Cavendish banana plantlets was at IBA $1.5 \mathrm{mg} \mathrm{L}^{-1}$ concentration with BA $3 \mathrm{mg} \mathrm{L}^{-1}$.

\footnotetext{
Funding: This study received no specific financial support.

Competing Interests: The authors declared that they have no conflict of interests.

Contributors/Acknowledgement: All authors participated equally in designing and estimation of current research.

Views and opinions expressed in this study are the views and opinions of the authors, Asian Journal of Agriculture and Rural Development shall not be responsible or answerable for any loss, damage or liability etc. caused in relation to/arising out of the use of the content.
}

\section{References}

Akpan, E. A., \& Udoh, V. S. (2017). Evaluation of cassava (manihot esculenta crantz) genotype for yield and yield component, tuber bulking, early maturity in cross river basin flood 
plains, itu, akwa ibom state, Nigeria. Canadian Journal of Agriculture and Crops, 2(2), 6873.

Avivi, S., \& Ikrarwati, I. (2004). Micropropagation of abaca banana (Musa textilis Nee) through tissue culture techniques. Pertan, 11(2), 27-34. view at Google scholar

Bhosale, U. P., Dubhashi, S. V., Mali, N. S., \& Rathod, H. P. (2011). In vitro shoot multiplication in different species of Banana. Asian J. of Plant Science and Research, 1(3), 23-27. view at Google scholar

Davies, P. J. (1995). Plant hormones and their role in plant growth and development. Boston: Martinus Nijhoff Publisher. view at Google scholar

Directorate General of Horticulture. (2015). 2014 Horticultural production statistics. Ministry of Agriculture. Jakarta.

Enjoni, E. (2004). Response of shoot tip explants (Citrus SP) to NAA and BAP concentrations on Initiation and shoot proliferation in vitro. S2 Thesis. Postgraduate Program of Andalas University. Padang. 61 p.

Fahmi, R. (2013). Study of the effect of cytokinin on plant growth. Center for Plantation Crops and Protection. Surabaya.

Flick, C. E., Evans, D. A., \& Sharp, W. R. (1993). Organogeneity. In D.A. Evans, W.R. Sharp, P.V. Amirato, and T. Yamada (eds.) Macmillan's Handbook of Plant Cell Culture Collier. London publisher. pp. 13-81.

Gardner, F. P., Pearce R. B., \& Mitchell, R. L. (1991). Physiology of crop plants. Translated by H. Susilo. Jakarta. University Indonesia Press. view at Google scholar

George, E. F., \& Sherrington, P. D. (1984). Plant propagation by tissue culture-handbook and directory of commercial laboratories. Exegetics Ltd., Edington.

Karjadi, A. K., \& Buchory, A. (2007). Effect of NAA and BAP on growth of garlic meristem in media B5. Journal of Horticulture., 17(3), 217-223.

Lestari, E. G. (2011). The role of growth regulating substances in plant propagation through tissue culture. J. Agrobiogen, 7(1), 63-68.

Lu, C. Y., \& Trevor, A. T. (1987). Somatic embryogenesis and plantlet regeneration in cultured immature embryos of Picea Glauca. Journal of Plant Physiology, 128(3), 297-302.

Okebiorun, E. O., \& Jatto, N. A. (2017). Value addition in cassava processing: evidence from women in ilesa west local government area of osun state. Agriculture and Food Sciences Research, 4(1), 30-36.

Putranto, K., \& Taofik, A. (2014). Pattern of diversification of food consumption of indigenous peoples of cireundeu village, cimahi city, West Java. Journal Istek, 8(1), 159-181.

Rahardja, P. C., \& Wiryanta, W. (2003). Various ways to increase plant. Agro Media Library.

Rahmawati, M., \& Hayati, E. (2013). Grouping based on character of vegetative morphology in banana germplasm from Aceh Besar. Journal Agrista, 17(3), 111-118.

Srivastava, L. M. (2002). Plant growth and development. Hormones and Environment. Academic Press. An imprint of Elsevier Science. California, USA .772p.

Subandi, M., Eri, M., \& Ari, S. (2018). The crossing effect of dragon fruit plant caltivars (Hylocereus Sp.) on Yield. International Journal of Engineering \& Technology, 7(2,29), 762-765. view at Google scholar / view at publisher

Subandi, M., Served, D., \& Firmansyah, E. (2018a). Production of reserpine of Rauwolfia serpentina (L) kurz ex benth through in vitro culture enriched with plant growth regulators of NAA and kinetin. International Journal of Engineering \& Technology, 7(2), 274-278. view at publisher

Supriati, Y. (2010). The efficiency of the banana podropagation kapok amorang through modification of the media formula and temperature. J. Agrobiogen, 6, 91100.

Supriyanto, A., Ernawanto, Q. D., \& Setiono, R. (1990). Orange growing media nursery. Horticulture Research, 5, 1-8.

Triningsih, T., Siregar, L. A. M., \& Putri, L. A. (2013). Growth of puar explants in vitro silence (Elettariopsis sp.). J. Online Agrotechnology, 1(2), 276-285. view at Google scholar 
Wattimena, G. A. (1988). Plant growth regulatory substances. Network Culture Laboratory. Biotechnology PAU Plant IPB. Bogor.

Yusnita, Y., \& Hapsoro, D. (2013). Exploration, characterization, selection, and in vitro clonal propagation to obtain Lampung commercial banana superior Genotypes. Featured Research Report. Lampung State University. Lampung.

Zulkarnain, W. M. (2009). Plant tissue culture. Earth Literacy. Jakarta, Indonesia 